EJEM

Econ.J.Emerg.Mark.
Economic Journal of Emerging Markets

Available athttp://journal.uii.ac.id/index.php/jep

\title{
Import competition and local labor markets: the case of Indonesia
}

\author{
Fina Sri Agustina
}

Department of Economics, Universitas Indonesia, Jakarta, Indonesia

Corresponding Author e-mail: finasriagustina@gmail.com

\begin{tabular}{l} 
Article Info \\
Article history: \\
Received: 16 March 2018 \\
Accepted: 21 June 2018 \\
Published: 1 October 2018 \\
\hline \\
Keywords: \\
import competition, local labor market, \\
Indonesia
\end{tabular}

JEL Classification:

F66, J21, J40

DOI: $10.20885 /$ ejem.vol10.iss2.art6

\begin{abstract}
This paper analyzes the effects of import competition on Indonesian local labor markets in term of manufacturing employment share, non-manufacturing employment share, unemployment rate, and wages. A rapid increase in globalization has caused many countries including Indonesia experiences a significant increase in imports, which leads to tougher import competition. Using data of imports from 430 districts in Indonesia in the period of 2007-2013, we find that import competition has negatively affected manufacturing employment share, non-manufacturing employment share, and wages. It also increases unemployment. Besides, the highest impact is mainly driven by imports of consumption goods.
\end{abstract}

\section{Introduction}

In the last two decades, the world has witnessed an increase in trade globalization. Many countries including Indonesia experienced a rapid increase in international trade. Under Indonesia's new competition law in 1998, Indonesia removed import restrictions and reduced import tariffs. There were five previous studies which mentioned the impact of import competition. According to Statistics Indonesia, the value of Indonesian imports increased significantly from 74,473 million U.S. dollars in 2007 to become 186,628 million U.S. dollars in 2013. However, during that period, the growth in workers who worked in manufacturing was very slow, and it even decreased in 2013. While those who work in the non-manufacturing sector steadily increased and wages slightly increased. Based on this, these are the research questions: Does a substantial increase in Indonesian imports affect Indonesian local labor markets regarding manufacturing employment share, non-manufacturing employment share, unemployment rate, and wages, and how significant is the impact? This paper investigates the impact of import competition on local labor markets in Indonesia.

Traditionally, the increase of trade globalization can benefit the countries involved. Due to trade openness, some industries may contract while others expand, however, the net results would be good for the economy as a whole. For example, the international trade which causes competition through imports tends to increase rivalry in industry and a decline in profits in many instances (Caves \& Porter, 1978). However, participation in international trade eventually increases productivity (Sjöholm, 1999). Therefore, local companies, which must compete with foreign companies both in the domestic and international markets, will be forced to increase their productivity by increasing efficiency and adopting new technologies.

On the other hand, a decrease in profits, an increase in efficiency and adoption of new technologies can also lead to a reduction in the number of the firms' workers and wages. As another example, labor demand for Mexican worker decreases because of the negative impact of import competition (Caamal-Olvera \& RangelGonzalez, 2015). Furthermore, trade openness triggered import exposure which leads to a decrease of demand for an unskilled worker in economies, such as Mexico (Feenstra \& Hanson, 1997), Chile (Pavcnik, 2003), and Indonesia (Kasaharaa, Liang, \& Rodrigue, 2016). In other words, import competition may cause unemployment (Dutt, Mitra, \& Ranjan, 2009; Hasan, Mitra, Ranjan, \& Ahsan, 2012).

In Indonesia, there are five previous studies, that mention the impact of import competition. First, Amiti and Konings (2007) show that in term of productivity, input tariffs reduction positively affects Indonesian employment through import competition. Second, Amiti and Cameron (2012) found that reducing intermediate input tariffs, however, causes the wages to skill premium in Indonesia to decrease. Third, Kis-Katos and Sparrow (2015) found that a reduction in import tariffs on intermediate goods increased the competitiveness of firms 
and induced the increase of low and medium skilled labor participation as well as the rise in wages for the medium skilled in Indonesia. Lastly, Kasaharaa et al. (2016) argued that a decision of firms in Indonesia to start importing causes higher demand for skilled labor. All in all, even though these five studies have not directly analyzed the effects of import competition on the labor market in Indonesia, most of them are optimistic toward trade liberalization.

However, despite a general belief among many economists that trade openness would benefit the economy, it seems that there was an observable phenomenon, such as a decrease in manufacturing employment share and wages, and an increase of unemployment in the labor market due to increased imports. His implies that the rapid increase in trade openness cannot be matched with adjustments in the labor market so that in 2013 scholars challenged the traditional view of the effects of globalization trading on the labor market by using new measures of import competition. The pioneers were Autor, Dorn, and Hanson (2013) who investigated the impact of Chinese import competition on local labor markets in the United States in 2013. They developed a new measurement of import competition that allows us to measure the import exposure faced by individual local labor markets. They found that Chinese import competition increased unemployment, and reduced the manufacturing employment share and wages, while for non-manufacturing the impact was negative but insignificant.

Following Autor et al. (2013), four researchers in other countries tried to conduct the same study using the same measurement of import competition. However, two of them also included exports in their research, while the others are focusing only on imports. Research that includes exports was conducted by Balsvik, Jensen, \& Salvanes (2014) and Dauth, Findeisen, \& Suedekum (2014). They examined the impact of Chinese import competition on the local labor markets in Norway and Germany, respectively. Balsvik et al. (2014) included export market exposure with a slightly different measurement. While, Dauth et al. (2014) included export exposure by using the same formula as Autor et al., but they replaced import value from China to Germany with the export value from Germany to China. Balsvik et al. (2014)found that Chinese import exposure reduced the share of manufacturing employment in Norway; however, it increased the public employees and workers in other sectors, while wages were unaffected. Dauth et al. (2014) concluded that imports from China hurt manufacturing employment, while exports from Germany to China exhibit a positive effect. Besides, Dauth et al. (2014) also analyzed the impact of Eastern Europe import competition on local labor markets in Germany. They found that imports from Eastern Europe also negatively affect manufacturing employment, while exports from Germany to Eastern Europe positively affect manufacturing employment. However, the impact of German imports and exports from and to Eastern Europe was stronger than the effect of German imports and exports from and to China. They argue that this is evidence that is focusing only on China will give an incomplete picture.

Two other pieces of research that focused only on imports similar to Autor et al. are research conducted by Donoso, Martin, \& Minondo (2014) in Spain and by Mendez (2015) in Mexico. Donoso et al. (2014) found that a substantial increase in imports from China negatively affected the manufacturing employment share in the labor markets of Spanish provinces. However, the increase in non-manufacturing employment offset this impact. Mendez (2015) found a negative impact on manufacturing employment share and unemployment in Chinese import competition. However, for non-manufacturing, the impact was also negative but insignificant. He also shows evidence that Chinese import competition has a small significant positive impact on wages. Like Autor et al. (2013), Donoso et al. (2014)and Mendez (2015), this paper focuses only on imports because we are interested in examining the impact of a significant increase in imports that began to exceed exports.

Based on the previous research, by using the new measurement of import exposure developed by Autor et al. (2013) and applying the same method as previous studies in those five countries, this paper examines how exactly import competition impacts on local labor markets in Indonesia. Furthermore, research that analyzes the effect of import competition on local labor markets in Indonesia still does not exist. Considering that understanding the impact of import competition on local labor markets is important as a policymaker consideration and given the lack of studies on the subject in Indonesia, this paper tries to fill this gap by conducting such research.

The structure of the rest of this paper will be as follows. Section 2 provides a brief explanation of the methodology, section 3 describes the data, section 4 presents our estimation results and discussion. Finally, section 5 concludes.

\section{Research Method}

This paper uses the same model and measurement of import exposure as Autor et al. (2013). However, the division of local labor markets is based on districts. Changes in exposure to import competition in the district are defined as changes in national imports of industrial products j during the period corresponding to the district 
share of total national employment in the industry at the beginning of the period. Then, the number of changes in imports of all industries was scaled to the total employment in the district $i$ at the beginning of the period. Mathematically, the changes of exposure to import competition can be written as the following:

$\Delta \exp _{i t}^{I D}=\frac{1}{L_{i t}} \sum_{j} \frac{L_{i j t}}{L_{j t}} \Delta M_{j t}^{I D}$

$\Delta \exp _{i t}^{I D} \quad$ : The changes of exposure to import competition.

$L_{i t} \quad:$ Total employment in district $\mathrm{i}$ in the start of the period.

$L_{i j t} \quad:$ The employment in district $\mathrm{i}$ in industry $\mathrm{j}$ in the start of the period.

$L_{j t} \quad:$ Total employment in Indonesia in industry j at the start of the period.

$\Delta M_{j t}^{I D} \quad$ : Change of Indonesian imports in industry $\mathrm{j}$ from the start to the end of the period.

We construct our baseline model based on the theoretical framework of the previous research. Theoretically, the changes in wages and employment are affected by the changes in import exposure, which is measured as in equation (1). Furthermore, according to previous research conducted by Autor et al. (2013), Balsvik et al. (2014), and Mendez (2015, some demographic characteristics may also affect the changes of wages and employment in district i. Besides, local labor market outcomes are also affected by the growth of the working-age population (Donoso et al., 2014). Hence, we will control these variables when estimating the impact of import competition on local labor markets. All in all, the regression model is as the following:

$\Delta y_{i t}=\beta_{1} \Delta \exp _{i t}^{I D}+X_{i t}{ }^{\prime} \beta_{2}+\varepsilon_{i t}$

$\Delta y_{i t} \quad$ : 3-year changes of manufacturing employment share, 3-year changes of non-manufacturing employment share, 3-year changes of the unemployment rate, or 3-year changes of In average wages in the region i from the start to the end of the period.

$\Delta \exp _{i t}^{I D}$ : The change of exposure to import competition.

$X_{i t} \quad$ : Control variables consist of growth of working age population, percentages of manufacturing employment, percentages of non-manufacturing employment, percentages of unemployment, In average wages, percentages of working for an aged population with a college education, and percentages of employment among working age women in district i at the start of a period.

According to Autor et al. (2013), there is a possibility that the realized imports were caused not only by the growing productivity of exporter countries and the fall of trade costs but also industry import demand shock in the importing country. In the case that import shock is driven by domestic demand shocks, OLS estimation may understate the real impact of import competition. To overcome the problem of endogeneity using a strategy, the same as Author et al. (2013), with some adjustments. The variable of the change of exposure to import competition $\left(\Delta \exp _{i t}^{I D}\right)$ is instrumented by the change of the world import exposure $\left(\Delta \exp _{i t}^{w}\right)$ and the change of the nonIndonesia import exposure $\left(\Delta \exp _{i t}^{o}\right)$. The first instrumental variable is constructed using data of world imports, while the second instrument is formulated using data of imports from world to other eight lower-middle-income countries in Asia. ${ }^{1}$ The formula of the instrumental variable is as follows:

$$
\begin{aligned}
& \Delta \exp _{i t}^{W}=\frac{1}{L_{i t-1}} \sum_{j} \frac{L_{i j t-1}}{L_{j t-1}} \Delta M_{j t}^{w} \\
& \Delta \exp _{i}^{o}=\frac{1}{L_{i t-1}} \sum_{j} \frac{L_{i j t-1}}{L_{j t-1}} \Delta M_{j t}^{o}
\end{aligned}
$$

Basically, the formula is similar with the formula to calculate the change of exposure to import competition $\left(\Delta \exp _{i t}^{I D}\right)$ except for two terms. Firstly, the change of realized Indonesian imports by industry $\left(\Delta M_{j t}^{I D}\right)$ is replaced by the change of realized world imports $\left(\Delta M_{j t}^{w}\right)$ and imports from the world to other lower-middle-income countries in Asia $\left(\Delta M_{j t}^{O}\right)$. Secondly, the level of employment lagged by one period. The idea behind the instrument variable is that the rise of the world economy leads to supply shocks and increased import penetration for all trading partners, not just for Indonesia. Therefore, using the world imports and import flows to other lower-middle-income countries in Asia as an instrument for local import exposure in Indonesia can identify the exogenous component of rising competitiveness in the world that is faced by lower-middle-income countries especially in the same region.

\footnotetext{
${ }^{1}$ The eight selected lower-middle-income countries are Cambodia, Philippines, Viet Nam, India, Pakistan, Bangladesh, Sri Lanka, and Bhutan. The eight countries are selected because they are the same lower middle-income country as Indonesia based on The World Bank country classification and their trade data for full sample period are available in UN Comtrade Database.
} 
Moreover, that can clear the effects of possible shocks that simultaneously affect Indonesian imports and regional performance. We use two instruments because according to Soderbom (2009), having more instruments than strictly required to enable us to improve the precision of estimates and test the validity of the instrumental variables through an overidentification test. We use a lag of the employment by one period to overcome the problem of measurement error or reverse causality if workers or manufacturers had anticipated future trade exposure and take some anticipatory actions.

The estimation method that is used is two stages least squared (2SLS) with fixed effects. The district's time-invariant effects that are possibly correlated with regressors will be eliminated by using fixed effects to avoid bias estimators. Furthermore, robust standard errors are clustered on a province, and the model is weighted by the start of period district's share of national population.

\section{Data}

This research uses a panel data analysis covering 430 districts in Indonesia from 2007-2013, which is divided into two periods: 2007-2010 and 2010-2013. The data on employment, wages, and Indonesian imports are from Statistics Indonesia. The world import data and the data on imports from the world to eight selected lower-middleincome countries in Asia was obtained from UN Comtrade Database. ${ }^{2}$ Besides, to distribute imports into several sectors of industry, we convert the import value from the Harmonized System Codes (HS) into the Standard Classification Codes of Indonesian Business Sector by using a concordance table from the publication "KBKI correspondence widenganth KKI 1998/1999 KKI 1998 HS" provided by Statistics Indonesia. While, the categorization of imported commodities into capital goods, intermediate goods, and consumption goods is based on the classification of Broad Economic Category (BEC). Furthermore, all the import values are inflated to 2009 U.S. dollars using the Personal Consumption Expenditures (PCE) deflator from the Bureau of Economic Analysis. The data used in this paper along with its sources can be seen in table 1.

Table 1. Summary of Data Source

\begin{tabular}{|c|c|c|}
\hline Variable & $\begin{array}{c}\text { Unit of } \\
\text { Measurement }\end{array}$ & Data Source \\
\hline \multicolumn{3}{|l|}{ Dependent variable } \\
\hline 3-year changes of manufacturing employment share & Percent & Statistics Indonesia \\
\hline 3-year changes of non-manufacturing employment share & Percent & Statistics Indonesia \\
\hline 3-year changes in the unemployment rate & Percent & Statistics Indonesia \\
\hline 3-year changes of ln average wages & Percent & Statistics Indonesia \\
\hline \multicolumn{3}{|l|}{$\begin{array}{l}\text { Component to calculate the change of import exposure and } \\
\text { instrumental variable }\end{array}$} \\
\hline Employment by industry and district & People & Statistics Indonesia \\
\hline Total employment in Indonesia by industry & People & Statistics Indonesia \\
\hline Total employment in Indonesia by a district & People & Statistics Indonesia \\
\hline Indonesian import value & Thousand US\$ & Statistics Indonesia \\
\hline Import value of 8 other lower-middle-income countries & Thousand US\$ & UN Comtrade \\
\hline World import value & Thousand US\$ & UN Comtrade \\
\hline \multicolumn{3}{|l|}{ Control variables } \\
\hline$\%$ manufacturing employment & Percent & Statistics Indonesia \\
\hline$\%$ non-manufacturing employment & Percent & Statistics Indonesia \\
\hline$\%$ unemployment & Percent & Statistics Indonesia \\
\hline In average wages & Nat log point & Statistics Indonesia \\
\hline$\%$ working age with a college education & Percent & Statistics Indonesia \\
\hline$\%$ employment among women & Percent & Statistics Indonesia \\
\hline Working-age growth & Percent & Statistics Indonesia \\
\hline
\end{tabular}

\footnotetext{
${ }^{2}$ The data are in the form of HS 6-digits that enable us to aggregate the value of imports into the sectors classification used in Indonesia.
} 


\section{Results and Discussion}

\section{Manufacturing employment}

We start by examining the impact of import exposure on manufacturing employment share. The 2SLS regression of equation (2) on fixed effects with dependent variable 3-year changes of manufacturing employment share is presented in table 2 .

Table 2. Change in Manufacturing Employment Share and Import Exposure, 2SLS Fixed Effects Estimates

\begin{tabular}{|c|c|c|c|c|}
\hline \multirow[t]{2}{*}{ Variable } & \multicolumn{4}{|c|}{$\begin{array}{l}\text { Dependent variable: 3-year changes of manufacturing } \\
\text { employment share }\end{array}$} \\
\hline & Model 1 & Model 2 & Model 3 & Model 4 \\
\hline \multicolumn{5}{|l|}{$\Delta$ Exposure: } \\
\hline Total imports & $\begin{array}{l}-1.543 * * \\
(0.665)\end{array}$ & & & \\
\hline Capital goods & & $\begin{array}{l}-3.190 * * \\
(1.307)\end{array}$ & & \\
\hline Intermediate goods & & & $\begin{array}{l}-2.774^{*} \\
(1.425)\end{array}$ & \\
\hline Consumption goods & & & & $\begin{array}{l}-27.221 * * * \\
(10.443)\end{array}$ \\
\hline \multicolumn{5}{|l|}{ Controls: } \\
\hline$\%$ manufacturing employment & $\begin{array}{l}-0.894 * * * \\
(0.170)\end{array}$ & $\begin{array}{l}-0.916 * * * \\
(0.171)\end{array}$ & $\begin{array}{l}-0.873 * * * \\
(0.176)\end{array}$ & $\begin{array}{l}-0.886 * * \\
(0.172)\end{array}$ \\
\hline$\%$ working age with college education & $\begin{array}{l}-0.234 \\
(0.165)\end{array}$ & $\begin{array}{l}-0.254 \\
(0.163)\end{array}$ & $\begin{array}{l}-0.206 \\
(0.167)\end{array}$ & $\begin{array}{l}-0.254 \\
(0.165)\end{array}$ \\
\hline$\%$ employment among women & $\begin{array}{l}-0.039 * * \\
(0.019)\end{array}$ & $\begin{array}{l}-0.041 * * \\
(0.017)\end{array}$ & $\begin{array}{l}-0.037 * \\
(0.020)\end{array}$ & $\begin{array}{l}-0.041 * * \\
(0.018)\end{array}$ \\
\hline Working age growth & $\begin{array}{l}-0.017 \\
(0.024)\end{array}$ & $\begin{array}{l}-0.016 \\
(0.024)\end{array}$ & $\begin{array}{l}-0.018 \\
(0.025)\end{array}$ & $\begin{array}{l}-0.017 \\
(0.024)\end{array}$ \\
\hline Observations & 752 & 752 & 752 & 752 \\
\hline $\mathrm{R}^{2}$ & 0.379 & 0.389 & 0.365 & 0.385 \\
\hline
\end{tabular}

Source: Author's statistical results.

Note: Robust standard errors in parentheses are clustered on Province. Models are weighted by start of period district's share of national population. ${ }^{*} \mathrm{p}<0.10,{ }^{* *} \mathrm{p}<0.05,{ }^{* * *} \mathrm{p}<0.01$.

Model 1 shows evidence of a negative relationship between the change of exposure to import competition and to manufacture employment share from 2SLS estimates. An increase of US\$1,000 per worker in a district's total import exposure was associated with a $1.5 \%$ decline in manufacturing employment share. According to the regression results of model 2-4, the impact of import exposure on manufacturing employment is mostly driven by imports of consumption goods. It is most likely because consumption goods trigger direct competition since no further process is needed to enter the market directly. Furthermore, most firms in Indonesia produce consumption goods, so that their products compete with imports of consumption goods resulting in a high competition that can severely reduce the manufacturing employment share.

Although most of the Indonesian imports were intermediate goods, the impact of import exposure of these goods on manufacturing employment share was still the lowest compared to capital and consumption goods. According to the regression results of model 2-4, the impact of import exposure on manufacturing employment is mostly driven by imports of consumption goods. While increased imports of intermediate goods lead to the modest impact on manufacturing employment share. It is most likely because intermediate goods may be used as intermediate inputs for manufacturing firms in the district so that it does not increase the competition between imported goods and products produced by local manufacturing firms. On the other hand, consumption goods trigger direct competition since no further process is needed to enter the market directly. Furthermore, most firms 
in Indonesia produce consumption goods, so that their products compete with imports of consumption goods resulting in a high competition that can severely reduce the manufacturing employment share.

The result in manufacturing is not an uncommon finding. Previous studies conducted by Autor et al. (2013), Donoso et al. (2014), Balsvik et al. (2014), Dauth et al. (2014) and Mendez (2015), found that import competition negatively affected the share of manufacturing employment. It means that our results confirm the findings of previous studies that manufacturing firms react to import competition by decreasing their employment.

\section{Non-manufacturing employment}

The 2SLS estimates of the relationship between exposure to import competition and non-manufacturing employment share are reported in table 3. The coefficient of the change of total import exposure was -2.9 , this means that a US\$1,000 increase in a district's total import exposure per worker is predicted to reduce the share of non-manufacturing employment by $2.9 \%$. For each type of imported goods, the impact of import exposure on the non-manufacturing employment share was also negative. An increase of a US\$1,000 per worker in import exposure of capital goods would increase the share of non-manufacturing employment by $6.8 \%$. It was higher than the impact of intermediate goods import exposure which was $4.0 \%$, however, compared to the impact of import exposure of consumption goods, the effect of capital goods import exposure was much lower.

Compared to the impact on manufacturing employment, the effects on non-manufacturing employment, in absolute value, is greater. If we look at the structure of employment in Indonesia, the share of non-manufacturing employment in Indonesia was higher than manufacturing employment. Most firms in Indonesia engaged in the non-manufacturing sector. Thus, it is likely that the affected workers and firms in nonmanufacturing are also larger than in manufacturing. Overall, the evidence of the impact of import competition on the non-manufacturing employment share supports the results reported in the study conducted by Dauth et al. (2014) in Germany.

Table 3. Change in Non-Manufacturing Employment Share and Import Exposure, 2SLS Fixed Effects Estimates

\begin{tabular}{|c|c|c|c|c|}
\hline \multirow[t]{2}{*}{ Variable } & \multicolumn{4}{|c|}{$\begin{array}{c}\text { Dependent variable: 3-year changes of non-manufacturing } \\
\text { employment share }\end{array}$} \\
\hline & Model 1 & Model 2 & Model 3 & Model 4 \\
\hline \multicolumn{5}{|l|}{$\Delta$ Exposure: } \\
\hline Total imports & $\begin{array}{l}-2.856^{* * *} \\
(0.981)\end{array}$ & & & \\
\hline Capital goods & & $\begin{array}{l}-6.765 * * * \\
(2.089)\end{array}$ & & \\
\hline Intermediate goods & & & $\begin{array}{l}-4.045^{*} \\
(2.089)\end{array}$ & \\
\hline Consumption goods & & & & $\begin{array}{l}-62.351 * * * \\
(16.619)\end{array}$ \\
\hline \multicolumn{5}{|l|}{ Controls: } \\
\hline$\%$ non-manufacturing employment & $\begin{array}{l}-1.115^{* * *} \\
(0.045)\end{array}$ & $\begin{array}{l}-1.127 * * * \\
(0.041)\end{array}$ & $\begin{array}{l}-1.090^{* * *} \\
(0.053)\end{array}$ & $\begin{array}{l}-1.144 * * * \\
(0.044)\end{array}$ \\
\hline$\%$ working age with college education & $\begin{array}{l}0.891 * * * \\
(0.246)\end{array}$ & $\begin{array}{l}0.848^{* * *} \\
(0.258)\end{array}$ & $\begin{array}{l}0.936 * * * \\
(0.235)\end{array}$ & $\begin{array}{l}0.833^{* * *} \\
(0.253)\end{array}$ \\
\hline$\%$ employment among women & $\begin{array}{l}-0.142^{* * *} \\
(0.038)\end{array}$ & $\begin{array}{l}-0.147 * * * \\
(0.038)\end{array}$ & $\begin{array}{l}-0.143^{* * *} \\
(0.040)\end{array}$ & $\begin{array}{l}-0.138^{* * *} \\
(0.036)\end{array}$ \\
\hline Working age growth & $\begin{array}{l}-0.014 \\
(0.027)\end{array}$ & $\begin{array}{l}-0.012 \\
(0.027)\end{array}$ & $\begin{array}{l}-0.017 \\
(0.026)\end{array}$ & $\begin{array}{l}-0.012 \\
(0.027)\end{array}$ \\
\hline Observations & 752 & 752 & 752 & 752 \\
\hline $\mathrm{R}^{2}$ & 0.533 & 0.544 & 0.523 & 0.548 \\
\hline
\end{tabular}

Source: Author's statistical results.

Note: Robust standard errors in parentheses are clustered on Province. Models are weighted by start of period district's share of national population. ${ }^{*} \mathrm{p}<0.10,{ }^{* *} \mathrm{p}<0.05,{ }^{* * *} \mathrm{p}<0.01$. 


\section{The unemployment rate}

The detailed 2SLS estimates of the impacts of import exposure on non-manufacturing employment are presented in table 4. Model 1 indicates that an increase of US\$1,000 per worker in a district's total import exposure was associated with an increase in the unemployment rate of $3.1 \%$. In model $2-4$, we replicate the regression by replacing the total import exposure with import exposure of capital goods, intermediate goods, and consumption goods respectively. From model $2-4$, we can see that imports of consumption goods mainly drove the negative coefficient of total import exposure. The effect of imports of capital and intermediate goods was modest.

Table 4. Change in The Unemployment Rate and Import Exposure, 2SLS Fixed Effects Estimates

\begin{tabular}{|c|c|c|c|c|}
\hline \multirow[t]{2}{*}{ Variable } & \multicolumn{4}{|c|}{$\begin{array}{l}\text { Dependent variable: 3-year changes of the unemployment } \\
\text { rate }\end{array}$} \\
\hline & Model 1 & Model 2 & Model 3 & Model 4 \\
\hline \multicolumn{5}{|l|}{$\Delta$ Exposure: } \\
\hline Total imports & $\begin{array}{l}3.143 * * * \\
(0.400)\end{array}$ & & & \\
\hline Capital goods & & $\begin{array}{l}7.075^{* * *} \\
(0.869)\end{array}$ & & \\
\hline Intermediate goods & & & $\begin{array}{l}4.837 * * * \\
(1.002)\end{array}$ & \\
\hline Consumption goods & & & & $\begin{array}{l}60.001 * * * \\
(7.635)\end{array}$ \\
\hline \multicolumn{5}{|l|}{ Controls: } \\
\hline$\%$ unemployment & $\begin{array}{l}-1.336^{* * *} \\
(0.123)\end{array}$ & $\begin{array}{l}-1.382 * * * \\
(0.131)\end{array}$ & $\begin{array}{l}-1.250 * * * \\
(0.111)\end{array}$ & $\begin{array}{l}-1.375^{* * *} \\
(0.137)\end{array}$ \\
\hline$\%$ working age with college education & $\begin{array}{l}-0.215^{* *} \\
(0.099)\end{array}$ & $\begin{array}{l}-0.191 * \\
(0.100)\end{array}$ & $\begin{array}{l}-0.234 * * \\
(0.097)\end{array}$ & $\begin{array}{l}-0.178^{*} \\
(0.096)\end{array}$ \\
\hline$\%$ employment among women & $\begin{array}{l}-0.018 \\
(0.017)\end{array}$ & $\begin{array}{l}-0.009 \\
(0.018)\end{array}$ & $\begin{array}{l}-0.025 \\
(0.016)\end{array}$ & $\begin{array}{l}-0.015 \\
(0.020)\end{array}$ \\
\hline Working age growth & $\begin{array}{l}0.014^{*} \\
(0.008)\end{array}$ & $\begin{array}{l}0.013 * \\
(0.008)\end{array}$ & $\begin{array}{l}0.016^{* *} \\
(0.008)\end{array}$ & $\begin{array}{l}0.014^{*} \\
(0.008)\end{array}$ \\
\hline Observations & 752 & 752 & 752 & 752 \\
\hline $\mathrm{R}^{2}$ & 0.605 & 0.633 & 0.573 & 0.620 \\
\hline
\end{tabular}

Source: Author's statistical results.

Note: Robust standard errors in parentheses are clustered on Province. Models are weighted by start of period district's share of national population. ${ }^{*} \mathrm{p}<0.10,{ }^{*} \mathrm{p}<0.05,{ }^{* * *} \mathrm{p}<0.01$.

According to the results, import competition increases unemployment. It may also be a consequence of the negative impact of import competition on manufacturing and non-manufacturing employment. In other words, the reduction of manufacturing and non-manufacturing employment causes some workers to lose their jobs and become unemployed. However, according to Statistics Indonesia, the unemployment rate in Indonesia during the period of 2007-2013 exhibited a decreasing trend, while the number of employment showed a slightly increasing trend. The possible reason is that there was an increase in employment in other sectors outside manufacturing and non-manufacturing. Another possibility is that there may be positive effects from exports that compensated the negative effects of imports.

The findings of the impact of import competition on unemployment in this paper are by the results of studies conducted by Autor et al. (2013) and Donoso et al. (2014). However, the size of the impact is different, this paper shows that the unemployment effects in Indonesia are lower than found by Autor et al. (2013) in the U.S., but it was higher than found by Donoso et al. (2014) in Spain. An increase of US\$1,000 per worker in import competition causes an increase in unemployment in the U.S. and Spain by $4,9 \%$ and $2.7 \%$, respectively. It may be because in the U.S. the impact of import competition on manufacturing employment was negative 
and, in absolute value, much higher than the finding in this paper so that the unemployment effects were also more sizeable. On the other hand, the effect of import competition on manufacturing employment in Spanish provinces was negative, but in absolute value, was lower than found in this study resulting in more modest unemployment effects.

\section{Wages}

The effect of import competition on wages is described in table 5. The results suggest that import competition had a negative effect on average wages. The first model shows the impact of total import exposure on ln average wages. The coefficient -1.6 implies that a US\$1,000 increase in a district's total import exposure per worker would decrease the In average wages by approximately 1.6 natural log points. In model 2-4, we explore wages effects from import exposure of capital goods, intermediate goods, and consumption goods separately. The results confirm that the largest decline was mainly driven by imports of consumption goods, while, the lowest fall was from imports of intermediate goods. It means that imports of consumption goods can lead to a significant decrease in wages. Imports of intermediate goods may only slightly decrease wages.

Compared with the previous studies, the relationship between import competition and wages is in line with the research findings of Autor et al. (2013). However, the magnitude of the impact is somewhat larger than that was found by Autor et al. (2013). It might be because the condition of most companies in Indonesia is still weaker than firms in the U.S., a negative impact experienced by the enterprises due to import competition, such as the decline in sales could lead to a significant decline in wages. Furthermore, the large labor force in Indonesia causes difficulty in finding jobs because people must compete with many job seekers so that even though the firms decrease their wages, workers tend to accept it.

Table 5. Change in Average Wages and Import Exposure, 2SLS Fixed Effects Estimates

\begin{tabular}{|c|c|c|c|c|}
\hline \multirow{2}{*}{ Variable } & \multicolumn{4}{|c|}{ Dependent variable: 3 -year changes of In average wages } \\
\hline & Model 1 & Model 2 & Model 3 & Model 4 \\
\hline \multicolumn{5}{|l|}{$\Delta$ Exposure: } \\
\hline Total imports & $\begin{array}{l}-1.635 * * * \\
(0.111)\end{array}$ & & & \\
\hline Capital goods & & $\begin{array}{l}-3.745 * * * \\
(0.213)\end{array}$ & & \\
\hline Intermediate goods & & & $\begin{array}{l}-2.465 * * * \\
(0.533)\end{array}$ & \\
\hline Consumption goods & & & & $\begin{array}{l}-33.708 * * * \\
(2.101)\end{array}$ \\
\hline \multicolumn{5}{|l|}{ Controls: } \\
\hline Ln average wages & $\begin{array}{l}-0.931 * * * \\
(0.098)\end{array}$ & $\begin{array}{l}-1.049 * * * \\
(0.074)\end{array}$ & $\begin{array}{l}-0.721 * * * \\
(0.136)\end{array}$ & $\begin{array}{l}-1.100 * * * \\
(0.070)\end{array}$ \\
\hline $\begin{array}{l}\% \text { working age with college } \\
\text { education }\end{array}$ & $\begin{array}{l}0.072 * * * \\
(0.026)\end{array}$ & $\begin{array}{l}0.053 * * * \\
(0.020)\end{array}$ & $\begin{array}{l}0.091 * * \\
(0.036)\end{array}$ & $\begin{array}{l}0.046 * * * \\
(0.018)\end{array}$ \\
\hline$\%$ employment among women & $\begin{array}{l}0.004 \\
(0.007)\end{array}$ & $\begin{array}{c}0.000 \\
(0.006)\end{array}$ & $\begin{array}{l}0.007 \\
(0.009)\end{array}$ & $\begin{array}{l}0.002 \\
(0.005)\end{array}$ \\
\hline Working age growth & $\begin{array}{l}-0.001 \\
(0.003)\end{array}$ & $\begin{array}{c}0.000 \\
(0.002)\end{array}$ & $\begin{array}{l}-0.002 \\
(0.005)\end{array}$ & $\begin{array}{l}0.000 \\
(0.002)\end{array}$ \\
\hline Observations & 752 & 752 & 752 & 752 \\
\hline $\mathrm{R}^{2}$ & 0.287 & 0.538 & 0.028 & 0.542 \\
\hline
\end{tabular}

Source: Author's statistical results.

Note: Robust standard errors in parentheses are clustered on Province. Models are weighted by start of period district's share of national population. ${ }^{*} \mathrm{p}<0.10,{ }^{* *} \mathrm{p}<0.05,{ }^{* * *} \mathrm{p}<0.01$. 


\section{Conclusion}

The impact of increased imports due to trade globalization on the labor market during the last two decades has been a concern of many researchers. Although trade openness would benefit the economy, if an adjustment in the labor market cannot match the rapid increase of trade globalization, the structure of employment and wages may be affected. Research on this issue is important, especially in the affected economies. This paper examines the impact of import competition on the local labor markets in Indonesia.

Using panel data analysis covering 430 districts in Indonesia, the estimation results show that the impact of a substantial increase in imports to Indonesia during the period of 2007-2013 affected the Indonesian local labor markets through import competition. Import exposure negatively affected manufacturing employment share, non-manufacturing employment share, and wages in Indonesia. In a more detailed analysis, we found that the effects of import competition on Indonesian local labor markets are mainly driven by imports of consumption goods rather than capital and intermediate goods.

Based on the evidence that the impact of import competition on both manufacturing and nonmanufacturing employment was negative, protecting employment by developing firms in both manufacturing and non-manufacturing is important. A possible way to protect employment is to assist for firms to increase the quality, variation, and innovation of their products so that they can compete with imported goods. Furthermore, the government can provide training to improve the skills of workers or to encourage them to become entrepreneurs. Providing better access to business loans is also important to help companies develop their businesses so that they can survive amid import exposure. It can also help people who lose their jobs and find it difficult to get new jobs to open their businesses. In this way, a decrease in employment and an increase in unemployment can be mitigated.

\section{References}

Amiti, M., \& Cameron, L. (2012). Trade liberalization and the wage skill premium: Evidence from Indonesia. Journal of International Economics, 87(2), 277-28.

Amiti, M., \& Konings, J. (2007). Trade liberalization, intermediate inputs, and productivity: Evidence from Indonesia. The American Economic Review, 97(5), 1611-1638.

Autor, D. H., Dorn, D., \& Hanson, G. H. (2013). The China syndrome: Local labor market effects of import competition in the United States. American Economic Review, 103(6), 2121-2168.

Balsvik, R., Jensen, S., \& Salvanes, K. G. (2014). Made in China, sold in Norway: Local labor market effects of an import shock. Journal of Public Economics, 127(C), 137-144.

Caamal-Olvera, C. G., \& Rangel-Gonzalez, E. (2015). Measuring the impact of the Chinese competition on the Mexican Labor Market: 1990-2013. North American Journal of Economics and Finance, 34(C), 351363.

Caves, R. E., \& Porter, M. E. (1978). Market structure, oligopoly, and stability of market shares. The Journal of Industrial Economics, 26(4), 289-313.

Dauth, W., Findeisen, S., \& Suedekum, J. (2014). The rise of the East and the Far East: German labor markets and trade integration (Düsseldorf Institute for Competition Economics (DICE) Discussion Paper No. 127).

Donoso, V., Martin, V., \& Minondo, A. (2014). Do differences in the exposure to Chinese imports lead to differences in local labour market outcomes? An analysis for Spanish provinces. Regional Studies, 49(10), 1746-1764.

Dutt, P., Mitra, D., \& Ranjan, P. (2009). International trade and unemployment: Theory and cross-national evidence. Journal of International Economics, 78(1), 32-44.

Feenstra, R. C., \& Hanson, G. H. (1997). Foreign direct investment and relative wages: Evidence of Mexico's maquiladoras. Journal of International Economics, 42(3-4), 371-393.

Hasan, R., Mitra, D., Ranjan, P., \& Ahsan, R. N. (2012). Trade liberalization and unemployment: Theory and evidence from India. Journal of Development Economics, 97(2), 269-280.

Kasaharaa, H., Liang, Y., \& Rodrigue, J. (2016). Does importing intermediates increase the demand for skilled 
workers? Plant-level evidence from Indonesia. Journal of International Economics, 102(2), 242-261.

Kis-Katos, K., \& Sparrow, R. (2015). Poverty, labor markets and trade liberalization in Indonesia. Journal of Development Economics, 117(C), 94-106.

Mendez, O. (2015). The effect of Chinese import competition on Mexican local labor markets. North American Journal of Economics and Finance, 34(C), 364-380.

Pavcnik, N. (2003). What explains skill upgrading in less developed countries? Journal of Development Economics, 71(2), 311-328.

Sjöholm, F. (1999). Exports, imports, and productivity: Results from Indonesian establishment data. World Development, 27(4), 705-715.

Soderbom, M. (2009). Applied econometrics, lecture 2: Instrumental Variables, 2SLS and GMM. Retrieved from http://www.soderbom.net/lec2n_final.pdf 